\title{
The role of psychological empowerment and job satisfaction on turnover intentions directly and indirectly through affective commitment on registered nurses in healthcare industry of twin cities (Islamabad and Rawalpindi) of Pakistan
}

\author{
Nosheen Rafiq ${ }^{1 *}$, Dr. Syed Haider Ali Shah ${ }^{2}$, Shakeel Sajjad ${ }^{3}$, Saleh Ahmed Salem Alyafei ${ }^{4}$ \\ ${ }^{1}$ M. Phil Scholar, Department of Management Sciences, Bahria University, Islamabad, Pakistan \\ ${ }^{2}$ Senior Assistant Professor, Faculty of Business Studies, Bahria University Islamabad, Pakistan \\ ${ }^{3}$ Research Associate, Department of Management Sciences, Bahria University Islamabad, Pakistan \\ ${ }^{4}$ MS (Finance), Faculty of Accounting and Finance, University of Malaya, Malaysia \\ *Corresponding author E-mail: haidershah11@gmail.com
}

\begin{abstract}
The shift from financial capital to the human capital has brought a significant change in the workplace and market. The role of nurses is getting crucial day by day and there is great need of retention of nurses in order to sustain the smooth operation of hospitals. Nurses' turnover has gained much importance and has become a concern for the hospitals. Psychological empowerment plays a vital role in retention of the employees and in return leads to success of the organization. Proper psychological empowerment and job satisfaction build such an environment that leads to develop people and enhance their affective commitment in industry like service industry, particularly in healthcare industry where the first impression of an organization is portrayed by their nurses. Researchers and practitioners have paid much of their attention to understand this phenomenon. The aim of the study is to investigate the role of psychological empowerment and job satisfaction on nurses' turnover intentions directly and indirectly through affective commitment. This study filled the gap by investigating such relationships in healthcare industry which has previously neglected, particularly at nurses level. A total of 520 questionnaires have been distributed in registered public and private hospitals located in twin cities of Pakistan. Structural Equation Modeling (SEM, AMOS) was employed to test hypotheses. This study showed relationships and interesting findings with mediation analysis. Findings of this study are important for top management of hospitals. In order to retain nurses, this study offers the theoretical and practical implications which could be used to enhance the affective commitment of nurses and reduce the turnover intentions.
\end{abstract}

Keywords: Psychological Empowerment; Job Satisfaction; Affective Commitment; Turnover Intentions; Registered Nurses; Structural Equation Modeling (Sem).

\section{Introduction}

In today's era, as life style is changing, healthcare industry is playing an essential role in people's lives because more people are becoming prey of diseases and needing adequate medical treatment [159], [89] and [176]. Nurses play a major role in the success of healthcare industry and have major responsibilities [84] and [115]. Success of healthcare organizations extensively depends on nurses so retention of qualified and experienced nurses is extensively important. Nurses involve in functions which are necessary to deliver healthcare services. Nurses work in collaboration with surgeons, therapist, physicians, patients, as well as patients' family [142]. Nurses' turnover is turning the worst due to chronic diseases among people around the world [103] and [148].

Nurses' turnover is a major challenge facing worldwide, as there are many factors that determine why registered nurses move to other gainful professions [11], [40], [108] and [132]. Pakistan is also facing high turnover among nurses [30], [8] and [129]. According to [128], turnover impacts healthcare organization's profit margin significantly which needs to be managed. Nurses' turnover extensively contributes to organizational costs and impacts quality of care [83] and [172]. High turnover leads to higher risks, costs and it impacts quality of performance among nurses [52], [68] and [55]. Nurses' turnover negatively affects in provision of quality service to patients and fulfilling their needs [39] and [69].

In healthcare industry, psychological empowerment (PE) is considered as important to reduce turnover intentions (TOIs) [59]. Employees who are psychologically empowered have more commitment towards their job which leads to higher level of performance [67] and [98]. Psychologically empowered employees always care for the organization and help in achieving organizational goals [162]. Researchers revealed that employees who are empowered respond quickly, enthusiastically and take responsibility of the service provision [18]. Empowerment results in responsiveness, synergy, employee commitment, efficiency, quality and competitiveness [99]. [162] showed that PE is linked with organizational commitment. PE significantly and positively influences affective commitment (AC) [3]. 
Job satisfaction (JS) is most of the time associated with nursing [39] and [87], absenteeism, turnover and retention [57] and [62]. According to [107], nurses who do not get satisfaction from their job show negative behaviours such as absenteeism, turnover intentions and burnout. In healthcare industry, top management keeps focus on work environment where work attributes to be linked to JS and positive consequences [146] and [169]. Nurses' job satisfaction contributes to the perceptual level of patient's satisfaction [170] and [168]. Job satisfaction is an important factor that influences quality of the healthcare services and safety of patients and it is contributes in turnover among nurses [148]. Job satisfaction predicts affective commitment among nurses [75]. Affective commitment is strongly associated with job satisfaction [9]. Those individuals who are not satisfied with their jobs, they do not show commitment with their organization [4]. [124] conducted a study among healthcare organization's employees and found that more satisfied employees have more organizational commitment. Similarly, JS predicts AC and TOIs and AC also predicts TOIs among nurses [56] and [26].

Affective commitment is another strongest predictor of turnover intentions among nurses [54]. Committed employees are those who have emotional attachment and engagement with their jobs [119]. It is the emotional attachment of an employee with his organization [120] and [58]. Affective commitment has negative and significant impact on turnover intentions, cognitions and their behaviour [62] and [130]. Various empirical studies have been conducted on turnover intentions among registered nurses but in western context. However, limited studies have been carried out in Pakistan [112], [113], [12], [106] and [15]. Furthermore, majority of them focused on telecom sector of Pakistan [147], [152] and [74]. There is a lack of empirical evidences on turnover intentions of registered nurses in developing countries, particularly in Pakistan which is a South Asian perspective. This study fills the gap by investigating the association among psychological empowerment, job satisfaction and turnover intentions with registered nurses of healthcare industry of Pakistan. Moreover, the mediating role of affective commitment is also examining in this study among registered nurses of healthcare industry of twin cities (Islamabad and Rawalpindi) of Pakistan which has previously neglected particularly in terms of empirical evidences. Nevertheless, this study focused on federal capital of Pakistan which is unique in its own terms as capital city represents the more focused population of registered nurses.

\section{Literature review}

\subsection{Turnover intentions}

Currenlty, turnover intentions is the most focused aspect for researches and practitioners [100] and [95]. Turnover is the most important concern for HR department [137]. Nurses' shortage is a severe problem, which would adversely impact in future and which is shifting attention towards development of nursing research and workplace factors such as wage, job satisfaction and other demographic factors which switch them from healthcare industry to non-healthcare industry [85]. Turnover defines that it is a situation where employee ceases to be the member of the organization [131]. According to the [82] and [83], when nurses transfer or leave their jobs within healthcare organization, turnover occurs. The intention to leave the current job is known as turnover intention [165].

Researchers and practitioners give more attention to turnover intentions rather than actual turnover because those nurses who left the job are more difficult to find out so focus is placed on nurses who are currently present on job but intentions to leave the job exists among them. It is a dire need of organizations to investigate employees' turnover intentions so that they make necessary precautions to stop them [165]. Willingness of employees to stay or leave the organization voluntarily is known as turnover intentions [134]. Leaving intentions are early signs of actual nurses' turnover [35]. According to different studies, behavioral intention of turnover is the best way to predict the actual turnover [5], [70] and [37]. According to a well-established study, turnover and turnover intentions have very strong relationship with each other but use of turnover intentions is supported [31]. Turnover intention is an important antecedent of turnover and it predicts actual turnover behaviour [62]. According to [34], leaving intentions mean to leave the healthcare organization.

When nurses leave their job, healthcare organizations face heavy costs. Cost of turnover is treated as loss for an organization [111]. This cost arises in the form of advertisement and other functions of HR [2]. A study suggested that the estimated cost of nurses' turnover ranges from $\$ 10,000$ to $\$ 88,000$ per vacant post according to the hierarchal position while total cost starts from $\$ 0.55$ million to $\$ 8.5$ million in a healthcare unit [65]. According to the [128], turnover cost for bedside registered nurse is $\$ 52,100$ and ranges from $\$ 40,300$ to $\$ 64,000$ which results in average loss ranging from $\$ 4.4 \mathrm{M}$ to $\$ 6.9 \mathrm{M}$. Each percent change in registered nurse turnover will cost or save $\$ 328,400$ in an average healthcare organization. It shows an immense importance to decrease nurses' turnover intentions in healthcare industry. Pakistan is also facing rampant turnover in healthcare industry [127] and [158]. According to [113], Pakistan is not having sufficient number of nurses according to the needs of rising population rate. According to [48], total numbers of registered nurses are 103,777 while according to [47], total number of registered nurses were 62,651. It showed a noticeable increase in recruitment of registered nurses. However, the problem of nurses' shortage is still the same as it was 60,000 according to the Government of Pakistan [86]. According to [166], Pakistan Nursing Council (PNC) suggested nurse to patient ratio as 1:10 in general areas and in specialized areas as 2:1 but currently we are having nurse to patient ratio as 1:50 in Pakistan. Pakistan has 0.604 nurses per 1000 people as compare to WHO standards which prescribed 2.5 nurses per 1000 people [1].

These days keeping and improving organizational talent is the most important concern for managers of human resource development [51]. Currently organizations are dealing with talent scarcity and organziations are carefully thinking about retention and development of employees [46]. Nurses who do not have professional expertise and sufficient experience, effect patients' satisfaction and increases error rates [149]. Organizations are protecting their investments [29] and trying to retain employees by providing them more challenging tasks, and assignments which increases employees loyality with organziations [145].

\subsection{Psychological empowerment (PE) and turnover intentions (TOIs)}

Currently, researchers are focusing on psychological empowerment as it is considered as most pivotal source of intrinsic motivation [171]. Empirical studies have shown that psychological empowerment is important for workplaces which are facing shortage of nurses and low morale [67]. As a human resource management policy, psychological empowerment is considered as the source to decrease TOIs [49]. Nurses serve humanity and devote their emotions and mental resources in practice of life saving in healthcare delivery. Due to importance of their role, it is essential to make them psychologically empower. This helps them to be mentally and emotionally strong and they will be able to serve in the best way.

Psychological empowerment is the process where conditions cause powerlessness are identified and eliminated by giving self-efficacy [38]. According to [17], PE is defined as it motivates employees and increases their feeling of self-efficacy. [167] further investigated identified choice, competency, impact and meaning which are the dimensions of cognitive aspect of PE. 
Previous studies supported the association between PE and TOIs. [20] showed PE is an important predictor of turnover intentions among employees of manufacturing division. [174] found that four constructs of PE i.e. meaning, impact, competence and self-determination are negatively associated with turnover intentions among managers in South Africa. [90] showed that PE has significant and negative association with TOIs among employees of production areas. [6] conducted a study on hotel staff of 4-star and 5-star in Izmir, Turkey and found that psychological empowerment significantly and negatively influences turnover intentions. [135] conducted a study on middle level managers in Indian industrial sector and they showed a negative correlation between PE and TOIs in this sudy. [77] conducted a study on employees working in Malay-Chinese banking and insurance sector of Malaysia and showed an inverse and significant correlation between PE and TOIs. According to [21], a significant and negative association was found between PE and TOIs among managers of Indian industrial sector. [76] conducted a study on employees of middle level management of Hattar industry and showed that PE and TOIs has negative relationship with each other. To reduce turnover intentions, it is important to make nurses psychologically empower.

There are also some studies who did not support the association between PE and TOIs. [96] conducted a study on registered nurses and showed that major predictor of turnover intentions is job dissatisfaction and job satisfaction is predicted by PE. In the same way, [97] conducted a study on Canadian staff nurses and found that organizational commitment predicted PE as well as job satisfaction is predicted by psychological empowerment. [133] conducted a study on acute care nurses from two community healthcare organizations and one territory healthcare organization in United States and showed no association between PE and TOIs.

Based on the above disscussion, this study proposed the following hypothesis:

Hypothesis 1: PE has negative association with TOIs

\subsection{Job satisfaction (JS) and turnover intentions (TOIs)}

Job satisfaction is mentioned as the major contributor of intention to stay in international studies of nursing [32] and [164]. According to [73], an individual is completely satisfies with his job, when he is satisfied with physiological, psychological and environmental circumstances at his workplace. According to [109], satisfaction is an emotional response while intentions are the statements about specific behaviour. [175] defined job satisfaction as effective orientations of an individual towards his work roles at his workplace. [104] investigated the concept of JS which is the outcome of what one wants from organization in result of his services which is rendered to the organization according to his perception. Job satisfaction can be seen in an employee by seeing his passionate behavior towards his job [61]. According to [25], it is an individual's attitude towards his job. JS is also defined as it is the positive emotional orientation of an individual towards his job [141]. According to [161], job satisfaction is the feeling (positive or negative) about job.

[23] disscussed about 13 predictors that predict job satisfaction among nurses. It includes personality traits e.g. education, experience, locus of control and age while organziational traits include commitment, communication at peer and supervisory level, autonomy, stress, recognition, prefessionalism, fairness and routinization.

According to [123], JS is the most repeatedly studied variable with turnover. According to the study of [157], JS is the strong predictor of intention to stay in healthcare organizations. According to [163], constructs like job satisfaction comes in regularity with turnover intentions as it considered synonyms for each other. Same is found by [41] that JS is a strong predictor of intentions to leave the job. According to [69], JS is very important factor that predicts TOIs. [45] highlighted JS as a reason for high turnover in nursing.

Literature showed correlation between JS and TOIs. [102] investigated that JS significantly and inversely impacts TOIs among emergency nurses. [14] showed a direct and significant association between JS and TOIs. [94] showed that JS has significant and negative association with turnover intentions among nurses. [28] found that JS strongly and negatively related with TOIs among staff nurses of central China. [79] showed in their study that JS has significant and negative association with their turnover intentions among school, university and bank employees. [66] showed in their study that those nurses who are satisfied with their jobs, did not show intentions to leave their current jobs. [7] investigated that JS significantly and negatively impacts TOIs among nurses in Karachi. [57] showed a negative association between JS and TOIs among Italian nurses. [93] also found that JS has moderate and negative association with TOIs among nurses in Taiwan. [71] conducted a meta-analysis on U.S. federal agency employees and private sector employees. Findings of the study suggested that correlation between JS and turnover is negative and significantly different from zero. Moreover, employees from U.S federal agency are less likely to leave the organization than employees working in private sector, across levels of JS. [36] showed in their study that JS has significant and negatively association with turnover intentions among nurses. [157] conducted a study on nurses of Pakistan, India and Sri Lanka and showed that job satisfaction impacts turnover directly. [177] conducted a study and showed that JS is significantly correlated with turnover among nurses in Taiwan.

Many studies do not support the linkage between JS and TOIs. [134] suggested that satisfaction impacts voluntary job termination indirectly only through its impact on behavioural intentions among non-supervisory plant workers in a medium size food processing company. Some studies do not support the direct association between JS and TOIs [109] and [50]. [109] found that JS does not influence turnover intentions directly among staff nurses but it mediates the association between JS and TOIs through commitment while pay satisfaction has significant, direct and indirect influence on TOIs. [50] found that commitment strongly, directly, significantly and negatively influences turnover intentions. He also found an indirect association between satisfaction and TOIs through commitment among graduated business students. Based on the above disscussion, this study proposed the following hypothesis: Hypothesis 2: JS has negative relationship with TOIs.

\subsection{Psychological empowerment (PE) and turnover intentions (TOIs) with mediating effect of affective commitment (AC)}

Organizational commitment is the concept which is investigated by many researchers [125] and [155]. [119] introduced three component framework as affective commitment (AC), continuance commitement (CC) and normative commitment (NC) rather than types. AC is an employee's emotional attachment, identification and involvement with the workplace and he/she wants to continue his/her job and wants to be part of the organization [119]. CC is the awareness about the benefits and costs which employee gets from organization and incase, of leaving that job he/she has to get off with these costs and benefits from organization [119]. NC shows feelings of obligation to remain with the organization [119]. AC has the stronger relationship with nurses' intention to leave the job than NC and CC [122].

Affective commitment is a shared psychological state of employees about their sense of loyalty and desire to devote their physical and mental abilities towards achieving organizational goals [58]. Affective commitment is basically the intrinsic motivation which leads to positive behaviours and attitudes as compare to other forms of commitments [60]. It deals with how closely an individual is interested and relates himself to be part of the organization [121]. AC is an employee's emotional involvement and attachment with the organization [9]. 
[162] showed that psychological empowerment is linked with organizational commitment. According to the previous studies, psychologically empowered nurses are more committed with their jobs [154] and [162] that in result, reduces their turnover intentions [49]. According to [126], psychologically empowered employees trust their organizations, in result, positive organizational outcomes such as organization commitment [121] and negative organizational outcomes such as turnover decreases [91]. According to the study, empowerment helps to inculcate sense of commitment among employees through the process of reciprocation [101]. Reciprocity occurs when employees treat each other well, in return employees recompensate advantegous treatement that they received from the organization [150].

PE significantly and positively influences AC [3]. [80] found a significant positive relationship between meaning, competence, selfdetermination, impact (dimensions of PE) and AC among Indian IT industry. [3] conducted a study among Indian female nurses and showed a positive correlation between PE and affective commitment working in public and private healthcare organizations.

According to earlier researches, there is an inverse correlation between AC and TOIs among nurses [120] and [122]. AC has relationship with the decision of continuance and discontinuance of job [118]. [88] investigated a study and indicated the relationship between AC and TOIs for chronically ill employees. [136] proposed a study in which they found that AC has a negative association with TOIs.

[135] showed AC has significant negative relationship with TOIs. While PE is significantly and positively correlated with AC. [77] showed a positive and significant correlation between PE and AC. Moreover, they showed AC partially mediates the association between PE and turnover intentions. [76] showed that psychological empowerment also has positive relationship with AC. In this study, AC is negatively related with TOIs among employees of middle level management of Hattar industry.

Some studies do not support the association between AC and TOIs. According to [117], organizational commitment as combined variable significantly impacts TOIs among the clinical laboratory scientists in Ghana. But affective commitment did not significantly impacts turnover intentions among employees. Same results are found by [153]. They showed affective commitment and normative commitment do not significantly influence TOIs while continuance commitment significantly influences TOIs.

On the basis of above disscussion, this study proposed the following hypothesis:

Hypothesis 3: AC mediates the association between PE and TOIs.

\subsection{Job satisfaction (JS) and turnover intentions (TOIs) with mediating effect of affective commitment (AC)}

Current researches have shown the association between JS and organizational commitment in healthcare organizations [13]. JS is one of the important predictor of affective commitment [144].

Effectiveness and success of organizations crucially depends on job satisfaction [151]. Recent researchers are focusing their attention on job satisfaction due to its immense importance [151]. Highly satisfied employees tend to be committed with their organizations as well as their colleagues [92]. Job satisfaction is widely used variable in organizational behaviour research [143]. Those individuals are more committed with their jobs who are more satisfied with their jobs [63]. AC is more favorable type than other types of organizational commitment [119]. According to [81], AC is significant antecedent of turnover intentions.

According to [173], affective commitment is strongly associated with JS and nurses' intentions to leave [27] and [122]. Previous studies suggested that JS and AC both are the predictors of TOIs. [56] conduced a study and showed JS is inversely associated with TOIs and positively associated with AC. Moreover, AC mediates the association between JS and TOIs at individual level. [116] conducted a study among front desk staff as customer service representatives in Pakistani banks and investigated that JS has negative and significant influenece on TOIs. They also found negative relationship between AC and TOIs. [178] conducted an empirical study on employees of manufacturing company. Findings of this study suggested that JS has positive relationship with AC. It is also investigated the negative association between JS and TOIs.

[114] conducted a study and revealed JS is positively associated with AC among managers which shows those managers are willing to stay in the organization, who are happy with their jobs. [110] conducted a study among employees and investigated organizational commitment, JS and their possible influence on turnover intentions. Findings of this study disclosed that AC is negatively correlated with TOIs. The correlation between JS and TOIs is inverse and significant. In this study, five dimensions of job satisfaction are disscused: payment, colleagues, boss, promotions and work itself (adapted from [160]). Five dimensions of JS are negatively correlated with TOIs with different intensities.

[109] investigated in his study on staff nurses and found that JS does not influence TOIs directly but it mediates the association between JS and TOIs through commitment while pay satisfaction has significant, direct and indirect influence on TOIs. [50] conducted a study on graduated business students and also found that commitment strongly, directly, significantly and negatively influences turnover intentions. He also found an indirect association between JS and TOIs through commitment.

Based on the above discussion, following hypothesis is formed:

Hypothesis 4: AC mediates the association between JS and TOIs.

\section{Foundation of research framework}

Current framework of this study is formed on the basis of literature review. In this study, independent variables are PE and JS, dependent variable is TOIs and mediating variable is AC. The foundation of this study is formed on the basis of social exchange theory (SET). Those individuals reciprocate the exchange of obligation who receive favors [44]. SET suggests that exchanges of resources between two parties predict positive and negative outcome [43]. When two parties involve in exchange obligation, with the passage of time relationship evolve into loyalty, mutual commitment and trusting [43]. Those employees who receive economic and social-emotional resources from organization, employees repay in a different way to this organization as an obligation [156]. [72] argued that two or more parties try to take something more valuable than the cost they pay. [22] discussed that social exchanges are not only occurred in economic perspective but it is also left on an individual's decision. Prior literature showed that PE plays an important role in increasing AC and decreasing TOIs. As [33] affirmed that those employees are motivated to reciprocate the organization with extra-role behavior who are psychologically empowered and their behavior is the exchange obligation occurs in the result of psychological empowerment. SET anticipates that positive initiating boost affective commitment as relational reciprocating response [42]. In the same way, job satisfaction inculcates commitment among employees for their workplace, which is reciprocated in the form of positive behavior [24].

Numerous studies have shown that exchange relation among employer and employee does not only depend on economic perspective but also on socio-emotional perspective such as respect, support and recognition [156]. This study is based on the point that individuals get motivation through exchange process of giving and receiving benefits [43]. In this study, SET explains that PE and JS enhance AC which consequently decreases TOIs. 


\section{Theoretical framework}

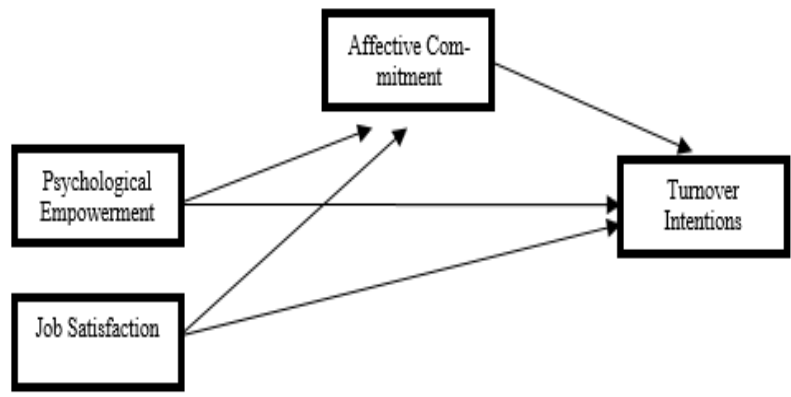

Fig. 1: Theoretical Framework.

\section{Methodology}

Nurses who are registered with Pakistan Nursing Council are the focus of this study. Stratas are made of public healthcare organizations and private healthcare organizations in twin cities of Pakistan. There are approximately 30 healthcare organizations; 19 public healthcare organizations and 11 private healthcare organizations. Only those registered healthcare organizations are taken for this study which are registered with Pakistan Medical and Dental Council. Out of 30 healthcare organizations, total 16 healthcare organizations participated in this study: 10 public healthcare organizations and 06 private healthcare organizations. Sample size from each strata has been taken on the basis of their proportion in the total population and then registered nurses were taken randomly. Total of 520 questionnaires were distributed among these healthcare organizations to HR department. 423 questionnaires were received back after filling and usable questionaires were 398 so the response rate was $81 \%$ (Table 1 ).

Table 1: Population and Sampling of Hospitals

\begin{tabular}{|c|c|c|c|}
\hline $\begin{array}{l}\text { Category of Healthcare Organi- } \\
\text { zation }\end{array}$ & $\begin{array}{l}\text { No. of Registered Nurses working in } \\
\text { Healthcare Organizations of Twin } \\
\text { Cities of Pakistan }\end{array}$ & $\begin{array}{l}\text { Total Number of Healthcare Organ- } \\
\text { izations in Twin Cities of Pakistan }\end{array}$ & Selected Healthcare Organizations \\
\hline Public & $4,240(63 \%)$ & $19(63 \%)$ & $10(63 \%)$ \\
\hline Private & $2,489(37 \%)$ & $11(37 \%)$ & $06(37 \%)$ \\
\hline Total & $6,729(100)$ & $30(100 \%)$ & $16(100 \%)$ \\
\hline
\end{tabular}

\section{Data collection and measurement of variables}

The questionnaire consisted of 26 items. Psychological empowerment has total 12 items. Psychological empowerment is adopted from the scale developed by [162]. 04 items related to job satisfaction are adopted from [78]. Moreover, affective commitment scale is adopted from [10] comprised on 06 items. 04 items of turnover intentions are adopted from [53]. All these items are measured on Likert Scale ranges from $1=$ strongly disagree to $5=$ strongly agree.

\section{Results and discussions}

The descriptive statistics of this study is given in table 2 .

Table 2: Descriptive Statistics

\begin{tabular}{llllll}
\hline Variables of the Study & Mean & Max. & Min. & Number & SD \\
\hline Psychological Empowerment & 3.11 & 5 & 1 & 398 & 1.023 \\
Job Satisfaction & 3.23 & 5 & 1 & 398 & 1.098 \\
Affective Commitment & 3.89 & 5 & 1 & 398 & 1.112 \\
Turnover Intentions & 3.65 & 5 & 1 & 398 & 1.101 \\
\hline
\end{tabular}

To analyze the hypotheses, Structural Equation Modeling (SEM) is applied by using AMOS. At first, reliability and validity is measured. Reliability is checked by average variance extracted (AVE), construct validity (CR) and Cronbach alpha (CB alpha). To investigate the construct validity convergent validity and discriminant validity are used. [179] presented the formula to calculate confirmatory factor analysis (CFA) for average variance extracted (AVE) and construct reliability (CR) which ascertained the reliability of the construct. Table 3 depicts the values of factor loading of all items ranges from 0.56 to 0.86 . Construct reliability ranges from 0.77 to 0.89 . Values of Average Variance Extracted (AVE) are greater than 0.50 as suggested by [16] to confirm the reliability. Values of Cronbach's alpha of all constructs are more than 0.70 which confirms the reliability of all constructs.

All the items used for this study are subject to confirmatory factor analysis (CFA). PE is measured by four dimensions (meaning, competence, self-determination and impact). These four dimensions are measured by total twelve items. In table 3, CFA indicates the factor loading of items ranged from 0.56 to 0.86 [64]. Further, construct of JS is measured by four items. In table 3, CFA showed that factor loadings of item 3 is low that is why excluded. CFA showed Factor loadings for other three items ranged from 0.71 to 0.78 [64]. Moreover, construct of AC is measured by six items. In table 3, CFA indicates that factor loading of item 2 is low so it is excluded. Factor loadings of remaining five items ranged from 0.68 to 0.81 [64]. The final construct of TOIs is measured by four items. In table 3, CFA indicates that factor loading of items from 0.61 to 0.79 [64]. 
Table 3: Construct Validity

\begin{tabular}{|c|c|c|c|c|c|}
\hline Constructs of the Study & Number of dimensions & Factor Loadings & AVE & $\mathrm{CR}$ & CB alpha \\
\hline \multirow[t]{12}{*}{ Psychological Empowerment } & PEM1 & 0.65 & 0.61 & 0.89 & 0.79 \\
\hline & PEM2 & 0.71 & & & \\
\hline & PEM3 & 0.57 & & & \\
\hline & PEC1 & 0.56 & & & \\
\hline & $\mathrm{PEC} 2$ & 0.63 & & & \\
\hline & PEC3 & 0.69 & & & \\
\hline & PESD1 & 0.65 & & & \\
\hline & PESD2 & 0.77 & & & \\
\hline & PESD3 & 0.86 & & & \\
\hline & PEI1 & 0.74 & & & \\
\hline & PEI2 & 0.82 & & & \\
\hline & PEI3 & 0.64 & & & \\
\hline \multirow[t]{3}{*}{ Job Satisfaction } & JS1 & 0.71 & 0.64 & 0.79 & 0.81 \\
\hline & JS2 & 0.73 & & & \\
\hline & JS4 & 0.78 & & & \\
\hline \multirow[t]{5}{*}{ Affective Commitment } & $\mathrm{AC} 1$ & 0.81 & 0.60 & 0.81 & 0.78 \\
\hline & $\mathrm{AC} 3$ & 0.75 & & & \\
\hline & $\mathrm{AC} 4$ & 0.69 & & & \\
\hline & AC 5 & 0.68 & & & \\
\hline & AC6 & 0.77 & & & \\
\hline \multirow[t]{4}{*}{ Turnover Intentions } & TOIs 1 & 0.61 & 0.57 & 0.77 & 0.84 \\
\hline & TOIs2 & 0.63 & & & \\
\hline & TOIs3 & 0.71 & & & \\
\hline & TOIs4 & 0.79 & & & \\
\hline
\end{tabular}

In table 4 bold values represent the square root of average variance extracted (AVE). To investigate the appropriateness of goodness of fit, confirmatory factor analysis (CFA) was employed. CFA results revealed inappropriate projected model. In order to attain the appropriate level of goodness of model fit, researcher discarded total two items, item 3 from job satisfaction and item 2 from affective commitment. This is done to achieve standardized factor loadings.

The initial goodness of fit model was [GFI=.687; CFI=.591; RMSEA=6.52; $\chi 2 / \mathrm{df}=14.654]$ and after discarding items according to [64], appropriateness of model was achieved and adjusted new summary was [GFI=.955; CFI=.945; RMSEA=.041; $\chi 2 / \mathrm{df}=3.258]$.

Keeping focus on the objectives of the study i.e. to investigate the mediating effect, the researcher adopted the approach of [140]. It investigated the impact of mediation in two stages: i) calculation of direct effect between independent and dependent variable without mediation ii) calculation of direct and indirect effects by involving mediation. In this study, bootstrapping method is used to investigate the indirect effect as literature supported to use the bootstrapping method [105] and [139].

Table 4: Comparison Correlations and Square Root AVE

\begin{tabular}{llllll}
\hline & AVE & Psychological Empowerment & Job Satisfaction & Affective Commitment & Turnover Intentions \\
\hline Psychological Empowerment & 0.61 & 0.76 & & & \\
Job Satisfaction & 0.64 & 0.510 & 0.81 & 0.77 & \\
Affective Commitment & 0.60 & 0.452 & 0.335 & -0.131 & 0.75 \\
Turnover Intentions & 0.57 & -0.056 & -0.039 & \\
\hline
\end{tabular}

The results of table 5 indicate the acceptance of $\mathrm{H} 1$, which showed that PE has significant negative association with TOIs. The coefficient value -0.789 showed that one unit change in PE brings 0.789 unit change in TOIs. Findings of this study are supported by previous studies. [20] showed a significant relationship between PE and TOIs among employees of manufacturing division. Further, [135] showed a negative association between PE and TOIs. [77] showed a negative and significant association between PE with TOIs among employees working in Malay-Chinese banking and insurance sector of Malaysia.

Table 5: Structural Model of Direct Hypothesis

\begin{tabular}{|c|c|c|c|c|c|c|c|}
\hline Hypothesis & Path & $\mathrm{B}$ & S. E & Standardized Estimates & C.R & P-Value & Decision \\
\hline H1 & PE $\rightarrow$ TOIs & -0.81 & 0.31 & -0.789 & -2.612 & 0.02 & Accepted H1 \\
\hline \multicolumn{8}{|c|}{ Table 6: Goodness of Fit of Direct Relation } \\
\hline Variables & & GFI & & CFI & RMSEA & & $\chi 2 / \mathrm{df}$ \\
\hline $\mathrm{PE} \rightarrow$ TOIs & & 0.945 & & 0.942 & 0.045 & & 4.652 \\
\hline
\end{tabular}

The results of table 7 showed the acceptance of $\mathrm{H} 2$, which presented that JS has significant negative correlation with TOIs. The coefficient value -0.691 revealed that one unit change in JS brings 0.691 unit change in TOIs. Literature also supported the relationship between JS and TOIs. [102] showed a significant and negative association between JS and TOIs among emergency nurses. [7] investigated that JS and TOIs has significant and inverse association with each other among nurses in Karachi. [94] revealed that JS has significant and negative relationship with TOIs among registered nurses in Samar Philippines.

Table 7: Structural Model of Direct Hypothesis

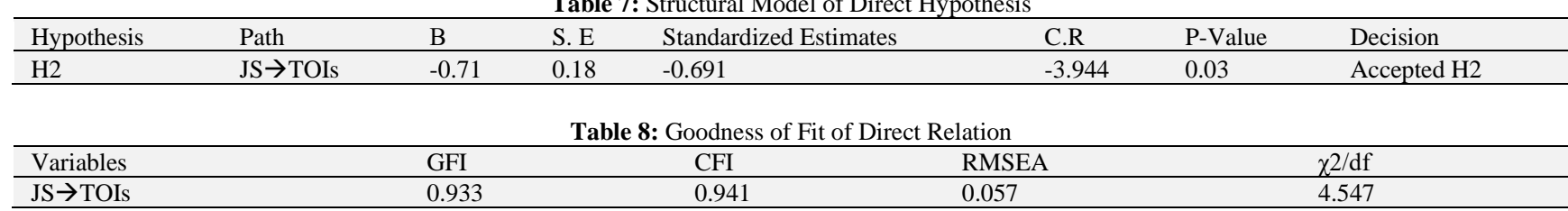


To investigate the mediating effect of AC between PE and TOIs, this study proposed H3 which showed AC mediates the relationship between PE and TOIs. To check the mediating effect of AC between JS and TOIs, this study developed H4, which showed AC mediates the association between JS and TOIs.

This study investigated the indirect effect of path PE $\rightarrow$ AC $\rightarrow$ TOIs. Table 9 indicates the direct effect of PE on TOIs without taking AC as a mediator was $-0.789, \mathrm{t}$ value as -2.612 and $\mathrm{P}$ value as 0.02 which indicated the significant direct effect of PE on TOIs. In the next step, $\mathrm{AC}$ as a mediating variable was taken and direct effect of $\mathrm{PE} \rightarrow \mathrm{TOIs}$ was analysed. The direct effect of PE on TOIs with AC as a mediating variable was $-0.721, \mathrm{t}$ value as -3.564 and $\mathrm{P}$ value as 0.04 in table 9. Thus the direct effect of $\mathrm{PE}$ on TOIs was significant after taking AC as a mediating variable. Further, to check the mediation, the indirect effect of path PE $\rightarrow$ AC $\rightarrow$ TOI was analysed. The indirect effect of PE on TOIs through mediation of affective commitment was -0.63 . Furthermore, to check the level of significance, the researcher used bootstrapping as prescribed by [138] with 1000 iteration to test the $\mathrm{P}$ value. The $\mathrm{P}$ value of indirect path was 0.005 which is below 0.05 . Results indicated the acceptance of $\mathrm{H} 3$ while illustrating that $\mathrm{AC}$ mediates the association between psychological empowerment and TOIs. According to [19], this is partial mediation. Table 9, showed that AC mediates the relationship between PE and TOIs. Results are inline with the study of [76] who also found a mediating effect of affective commitment between psychological empowerment and TOIs. Likewise, another study revealed that AC partially mediates the relationship between PE and TOIs [77].

To investigate the H4, similar method was applied. The study investigated the indirect effects of JS $\rightarrow$ AC $\rightarrow$ TOIs. Table 9, showed the direct effect of JS on TOIs without AC as a mediator in the model was -0.691 with $\mathrm{t}$ value as -3.944 and $\mathrm{P}$ value as 0.03 which exhibited the significant direct effect of JS and TOIs. In the next step, AC as a mediating variable was taken to investigate the direct influence of $\mathrm{JS} \rightarrow$ TOIs. The direct effect of JS on TOIs with AC as a mediating variable was -0.612 with $t$ value as -4.415 and $\mathrm{P}$ value as 0.01 . So the direct effect of JS on TOIs was significant after taking AC as a mediator. Further, to check the mediation, the indirect effect of path $\mathrm{JS} \rightarrow \mathrm{AC} \rightarrow \mathrm{TOI}$ was analysed. The indirect effect of JS on TOIs through mediation of AC was -0.51 in table 9 . Moreover, to examine the level of significance, the researcher used bootstrapping as suggested by [138] with 1000 iterations to test the $P$ value. The $P$ value of indirect path was 0.002 which is below 0.05 . Results showed that $\mathrm{H} 4$ is accepted and illustrate that AC acts as a mediating variable between JS and TOIs. [19] approach suggested it as a partial mediation. Previous studies also support these results. [56] showed in their study that AC mediates the association between JS and TOIs at individual level. [109] showed that AC mediates the association between JS and TOIs.

Table 9: Mediation Analysis (Indirect Effect) of Structural Model

\begin{tabular}{|c|c|c|c|c|c|c|c|c|c|}
\hline $\begin{array}{l}\text { Hypoth- } \\
\text { esis }\end{array}$ & Path & $\begin{array}{l}\text { Direct without } \\
\text { mediator }\end{array}$ & Sig & $\begin{array}{l}\text { Direct with } \\
\text { mediator }\end{array}$ & Sig & $\begin{array}{l}\text { Indirect } \\
\text { effect }\end{array}$ & $\begin{array}{l}\text { P-value (boot- } \\
\text { strap) }\end{array}$ & Mediation & Decision \\
\hline H3 & $\mathrm{PE} \rightarrow \mathrm{AC} \rightarrow \mathrm{TOIs}$ & -0.789 & $\begin{array}{l}- \\
2.612 \\
(0.02)\end{array}$ & -.721 & $\begin{array}{l}- \\
3.564 \\
(0.04)\end{array}$ & -0.63 & 0.005 & $\begin{array}{l}\text { Partial Me- } \\
\text { diation }\end{array}$ & $\begin{array}{l}\text { Accepted } \\
\text { H3 }\end{array}$ \\
\hline $\mathrm{H} 4$ & $\mathrm{JSA} \rightarrow \mathrm{AC} \rightarrow \mathrm{TOIs}$ & -0.691 & $\begin{array}{l}- \\
3.944 \\
(0.03)\end{array}$ & -.612 & $\begin{array}{l}- \\
4.415 \\
(0.01)\end{array}$ & -0.51 & 0.002 & $\begin{array}{l}\text { Partial Me- } \\
\text { diation }\end{array}$ & $\begin{array}{l}\text { Accepted } \\
\text { H4 }\end{array}$ \\
\hline
\end{tabular}

Table10: Goodness of Fit through AC

\begin{tabular}{llll}
\hline Variables & GFI & CFI & RMSEA \\
\hline $\mathrm{PE} \rightarrow \mathrm{AC} \rightarrow$ TOIs & 0.945 & 0.941 & 0.045
\end{tabular}

\section{Conclusion}

This study has various contributions to the existing body of knowledge from a Pakistani perspective. This study contributes to the understanding of impact of PE and JS on TOIs through mediating effect of affective commitment in context of Pakistan. When talented nurses with more years of experience leave healthcare organization, it proves harmful for organizational success and growth, and moreover, it effects overall productivity. It also demoralizes those nurses who left behind in the same healthcare organization.

In light of above results and discussion, it is concluded that psychological empowerment strongly (79\%) influences turnover intentions among registered nurses. Similarly, to enhance psychological empowerment, the role of AC as a mediator is very important and the results clearly indicated that mediation effect is strong $(63 \%)$ which ultimately decreases turnover intentions. It showed that affective commitment should be promoted in healthcare industry of Pakistan. Another finding of this study is that job satisfaction also significantly impacts turnover intentions which showed that job satisfaction strongly (69\%) plays its role in decreasing TOIs so the issue of nurses' JS needs to be addressed. In the same way, AC mediates the relationship between JS and TOIs. It showed the vital importance of AC in healthcare industry of Pakistan but affective commitment in healthcare industry is not properly being implemented. Results revealed that mediation effect is moderate $(51 \%)$ between JS and TOIs. Moderate result paved way for top management and practitioners to design and implement proper practices of job satisfaction, in order to build affective commitment which will result in the form of reduction in nurses' turnover intentions. These findings showed the similar results as previous [56], [116], [178] and [109].

In the healthcare industry, nurses are the foundation for success [159]. Healthcare industry's long term success depends on nurses. Top managers and HR practitioners of healthcare organizations should pay more attention to provide psychological empowerment and job satisfaction which can play a tremendous role in retention of nurses as well as improving quality service in healthcare organizations. Moreover, in order to make them affectively committed with their jobs, top managers could focus on nurses' development and make them feel valued so that nurses perceive them as a part of healthcare organizations and start building affective commitment with their jobs. Healthcare organization's top management could provide psychological empowerment and job satisfaction to enhance AC which in turn will decrease nurses' TOIs [89].

\section{Limitations and future recommendations}

This study has some limitations but these limitations can come up as a unique way for future research. First, this study has taken only registered nurses of the healthcare industry. Other employees can also be taken from healthcare and other different industries. Secondly, data only collected once so this is a cross sectional study. For future studies, longitudinal or experimental studies can be adopted. Another limitation is that, this study has taken only public and private healthcare organizations of twin cities (Islamabad and Rawalpindi) of Pakistan 
Therefore, this study can not be generalized on all cities of Pakistan. Future studies should target other service industries like education, telecom etc and the same framework can be tested over there. This study did not investigate other variables such as organizational citizenship behaviour, motivation and leadership so future studies could test impact of such variables.

\section{References}

[1] World Health Organization (2014). Density of nursing and midwifery personnel.

[2] Abbasi, S., Hollman, K., \& Hayes, R. (2008). Bad bosses and how not to be one. Information Management Journal, $42(1)$, 52-56.

[3] Aggarwal, A., Dhaliwal, R. S., \& Nobi, K. (2018). Impact of Structural Empowerment on Organizational Commitment: The Mediating Role of Women's Psychological Empowerment. The Journal of Business Perspective, 22(3), 284-294. https://doi.org/10.1177\%2F0972262918786049.

[4] Ahmad, S. (2013). Paradigms of quality of work life. Journal of Human Values, 19(1), 73-82. https://doi.org/10.1177\%2F0971685812470345.

[5] Ajzen, I., \& Fishbein, M. (1977). Attitude-Behavior Relations: A Theoretical Analysis and Review of Empirical Research. Psychological Bulletin, 84(5), 888-918.

[6] Akgunduza, Y., \& Bardakoglu, O. (2015). The impacts of perceived organizational prestige and organization identification on turnover intention: the mediating effect of psychological empowerment. Current Issues in Tourism, 20(14), 1510-1526. https://doi.org/10.1080/13683500.2015.1034094

[7] Alam, A., \& Asim, D. M. (2019). Relationship Between Job Satisfaction and Turnover Intention. International Journal of Human Resource Studies, 9(2), 163-194. https://doi.org/10.5296/ijhrs.v9i2.14618

[8] Ali, R. M., \& Wajidi, F. A. (2013). Factors influencing job satisfaction in Public Healthcare Sector of Pakistan. Global Journal of Management and Business Research, 13(8), 61-66

[9] Allen, N. J., \& Meyer, J. P. (1996). Affective, Continuance, and Normative Commitment to the Organization: An Examination of Construct Validity. Journal of Vocational Behaviour, 49(3), 252-276. https://doi.org/10.1006/jvbe.1996.0043.

[10] Allen, N., Meyer, J., \& Smith, C. (1993). Commitment to organizations and occupations: Extension and test of a three-component model. Journal of Applied Psychology, 78, 538-551.

[11] Almalki, M., FitzGerald, G., \& Clark, M. (2011). The nursing profession in Saudi Arabia: An Overview. International Nursing Review, 58(3), 304311. https://doi.org/10.1111/j.1466-7657.2011.00890.x

[12] Alsam, N., Imran, R., Anwar, M., Hameed, Z., \& Kafayat, A. (2013). The Impact of Work Family Conflict on Turnover Intentions: An Empirical Evidence from Pakistan. World Applied Sciences Journal, 24(5), 628-633. https://doi.org/10.5829/idosi.wasj.2013.24.05.13227.

[13] Alsaraireh, F., Griffin, M. T., Ziehm, S. R., \& Fitzpatrick, J. J. (2014). Job satisfaction and turnover intention among Jordanian nurses in psychiatric units. International Journal of Mental Health Nursing, 23(5), 460-467. https://doi.org/10.1111/inm.12070.

[14] Applebaum, D., Fowler, S., Fiedler, N., Osinubi, O., \& Robson, M. (2010). The impact of environmental factors on nursing stress, job satisfaction, and turnover intention. The Journal of Nursing Administration, 40(7/8), 323-328. https://dx.doi.org/10.1097\%2FNNA.0b013e3181e9393b.

[15] Ashar, M., Ghafoor, M., Munir, E., \& Hafeez, S. (2013). The impact of perceptions of training on employee commitment and turnover intention: Evidence from Pakistan. International Journal of Human Resource Studies, 3(1), 74-88. https://doi.org/10.5296/ijhrs.v3i1.2925.

[16] Bagozzi, R., Yi, Y., \& Nassen, K. (1998). Representation of measurement error in marketing variables: Review of approaches and extension to threefacet designs. Journal of Econometrics, 89(1-2), 393-421. https://doi.org/10.1016/S0304-4076(98)00068-2.

[17] Bandura, A. (1986). The Explanatory and Predictive Scope of Self- Efficacy Theory. Journal of Social and Clinical Psychology, 4(3), 359-373. https://doi.org/10.1521/jscp.1986.4.3.359.

[18] Barbee, C., \& Bott, V. (1991). Customer treatment as a mirror of employee treatment. Advanced Management Journal, 56(2), 27.

[19] Baron, R., \& Kenny, D. (1986). The moderator-mediator variable distinction in social psychological research: Conceptual, strategic and statistical considerations. Journal of Personality and Social Psychology, 51(6), 1173.

[20] Bester, J., Stander, M. W., \& Zy, L. E. (2014). Leadership empowering behaviour, psychological empowerment, organisational citizenship behaviours and turnover intention in a manufacturing division. SA Journal of Industrial Psychology, 41(1), 1-14. https://doi.org/10.4102/sajip.v41i1.1215.

[21] Bhatnagar, J. (2012). Management of innovation: role of psychological empowerment, work engagement and turnover intention in the Indian context. The International Journal of Human Resource Management, 23(5), 928-951. https://doi.org/10.1080/09585192.2012.651313.

[22] Blau, P. M. (1964). Justice in Social Exchange. Sociological Inquiry, 34(2), 193-206.

[23] Blegen, A. (1993). Nurses' job satisfaction : A meta-analysis of related variables. Nursing Research, 42(1), 36-41.

[24] Bowen, D., \& Ostroff, C. (2004). Understanding HRM-firm performance linkages: The role of the strength of the HRM system. Academy of Management Review, 29(2), 203-221.

[25] Brief, A. (1998). Attitudes in and around organizations. Thousand Oaks: CA: Sage.

[26] Brunetto, Y., Teo, S. T., Shacklock, K., \& Farr-Wharton, R. (2012). Emotional intelligence, job satisfaction, well-being and engagement: explaining organisational commitment and turnover intentions in policing. Human Resource Management Journal, 22(4), 428-441. https://doi.org/10.1111/j.1748-8583.2012.00198.x.

[27] Bycio, P., Hackett, R., \& Allen, J. (1995). Further assessments of Bass's (1985) conceptualization of transactional and transformational leadership. Journal of applied psychology, 80(4), 468-478.

[28] Cai, C., \& Zhou, Z. (2009). Structural empowerment, job satisfaction, and turnover intention of Chinese clinical nurses. Nursing and Health Sciences, 11(4), 397-403. https://doi.org/10.1111/j.1442-2018.2009.00470.x.

[29] Cappelli, P. (2008). Talent Management for the twenty first century. Harvard Business Review, 74-81.

[30] Cassum, L. A. (2014). Verbal violence at workplace: A reality from Pakistani context. Journal of Nursing Education and Practice, 4(8), 20-25.

[31] Castle, N. G., Engberg, J., Anderson, R., \& Men, A. (2007). Job Satisfaction of Nurse Aides in Nursing Homes: Intent to Leave and Turnover. The Gerontological Society of America, 47(2), 193-204. https://doi.org/10.1093/geront/47.2.193.

[32] Cavanagh, S. (1992). Job satisfaction of nursing staff working in hospitals. Journal of Advanced Nursing, 17(6), 704-711. https://doi.org/10.1111/j.1365-2648.1992.tb01968.x.

[33] Chan, Y. H., Taylor, R. R., \& Markham, S. (2008). The Role of Subordinates' Trust in a Social Exchange driven Psychological Empowerment Process. Journal of Managrial Issues, 20(4), 444-467.

[34] Chan, Z., Tam, W., Lung, M., Wong, W., \& Chau, C. (2012). A systematic literature review of nurse shortage and the intention to leave. Journal of Nursing Management, 21(4), 605-613. https://doi.org/10.1111/j.1365-2834.2012.01437.x.

[35] Che^nevert, D., Jourdain, G., \& Vandenberghe, C. (2016). The role of high-involvement work practices and professional self-image in nursing recruits turnover: A three-year prospective study. International Journal of Nursing Studies, 53, 73-84. https://doi.org/10.1016/j.ijnurstu.2015.09.005.

[36] Chen, I.-H., Brown, R., Bowers, B. J., \& Chang, W.-Y. (2015). Work-to-family conflict as a mediator of the relationship between job satisfaction and turnover intention. Journal of Advanced Nursing, 71(10), 2350-2363. https://doi.org/10.1111/jan.12706.

[37] Cohen, G., Blake, R. S., \& Goodman, D. (2016). Does Turnover Intention Matter? Evaluating the Usefulness of Turnover Intention Rate as a Predictor of Actual Turnover Rate. Review of Public Personnel Administration, 36(3), 240-263. https://doi.org/10.1177\%2F0734371X15581850.

[38] Conger, J. A., \& Kanungo, R. N. (1988). The Empowerment Process: Integrating Theory and Practice. Academy ol Management Review, 13(3), 471- 482. https://doi.org/10.5465/amr.1988.4306983.

[39] Coomber, B., \& Barriball, K. L. (2007). Impact of job satisfaction components on intent to leave and turnover for hospital-based nurses: a review of the research literature. International Journal of Nursing Studies, 44(2), 297-314. https://doi.org/10.1016/j.ijnurstu.2006.02.004.

[40] CORTESE, C. G. (2007). Job satisfaction of Italian nurses: an exploratory study. Journal of nursing management, 15(3), 303-312. https://doi.org/10.1111/j.1365-2834.2007.00694.x. 
[41] Cowin, L. S., Johnson, M., Craven, R. G., \& Marsh, H. W. (2008). Causal modeling of self-concept, job satisfaction and retention of nurses. International Journal of Nursing Studies, 45(10), 1449-1459. https://doi.org/10.1016/j.ijnurstu.2007.10.009.

[42] Cropanzano, R., Anthony, E. L., Daniels, S. R., \& Hall, A. V. (2017). Social Exchange Theory: A Critical Review with Theoretical Remedies. Academy of Management Annals, 11(1), 479-516. https://doi.org/10.5465/annals.2015.0099.

[43] Cropanzano, R., \& Mitchell, M. (2005). Social exchange theory: An interdisciplinary review. Journal of Management, 31(6), 874-900. https://doi.org/10.1177\%2F0149206305279602.

[44] Cropanzano, R., Rupp, D., Mohler, C., \& Schminke, M. (2001). Three roads to organizational justice. In G. R. Ferris (Ed.). Research in personnel and human resource management, 20, 1-123.

[45] Currie, E., \& Hill, R. C. (2012). What are the reasons for high turnover in nursing? A discussion of presumed causal factors and remedies. International Journal of Nursing Studies, 49(9), 1180-1189. https://doi.org/10.1016/j.ijnurstu.2012.01.001.

[46] D'Amato, A., \& Herzfeldt, R. (2008). Learning orientation, organizational commitment and talent retention across generations: A study of European managers. Journal of Managerial Psychology, 23(8), 929-953. https://doi.org/10.1108/02683940810904402.

[47] Economic Survey of Pakistan (2007-2008). Economic Adviser's Wing, Finance Division, Government of Pakistan.

[48] Economic Survey of Pakistan (2017-2018). Economic Adviser's Wing, Finance Division, Government of Pakistan.

[49] Eisenberger, R., Huntington, R., Hutchison, S., \& Sowa, D. (1986). Perceived Organizational Support. Journal of Applied Psychology, 71(3), 500507. https://psycnet.apa.org/doi/10.1037/0021-9010.71.3.500.

[50] Elangovan, A. (2001). Causal ordering of stress, satisfaction and commitment, and intention to quit: a structural equations analysis. Leadership \& Organization Development Journal, 22(4), 159-165. https://doi.org/10.1108/01437730110395051.

[51] Esmaeili, N. (2016). Importance of Talent Management in Reducing Employees' Turnover Intentions. International Journal of Humanities and Cultural Studies , 2019-2026.

[52] Fang, Y. (2001). Turnover propensity and its causes among Singapore nurses: an empirical study. International Journal of Human Resource Management, 12(5), 859-871.

[53] Farh, J. L., Tsui, A. S., Xin, K., \& Cheng, B. S. (1998). The influence of relational demography and guanxi: The Chinese case. Organization science, 9(4), 471-488. https://doi.org/10.1287/orsc.9.4.471.

[54] Fleig-Palmer, M., \& Rathert, C. (2015). Interpersonal mentoring and its influence on retention of valued health care workers: the moderating role of affective commitment. Health Care Management Review, 40(1), 56-64. https://Doi.10.1097/HMR.0000000000000011.

[55] Flinkman, M., Leino-Kilpi, H., \& S.Salantera. (2010). Nurses Intention to Leave the Profession: Integrative Review. Journal of Advanced Nursing, 66(7), 1422-1434. https://doi.org/10.1111/j.1365-2648.2010.05322.x

[56] Galletta, M., Portoghese, I., Carta, M. G., D’Aloja, E., \& Campagna, M. (2016). The Effect of Nurse-Physician Collaboration on Job Satisfaction, Team Commitment, and Turnover Intention in Nurses. Research in Nursing and Health, 39(5), 375-385. https://doi.org/10.1002/nur.21733

[57] Galletta, M., Portoghese, I., Penna, M. P., Battistelli, A., \& Saiani, L. (2011). Turnover intention among Italian nurses: The moderating roles of supervisor support and organizational support. Nursing and Health Sciences, 13(2), 184-191. https://doi.org/10.1111/j.1442-2018.2011.00596.x.

[58] Gardner, T. M., Wright, P. M., \& Moynihan, L. M. (2011). The impact of motivation, empowerment and skill enhancing practices on aggregate voluntary turnover: The mediating effect of collective affective commitment. Personnel Psychology, 64(2), 315-350. https://doi.org/10.1111/j.17446570.2011.01212.x.

[59] Gkorezis, P., \& Petridou, E. (2008). Employee psychological empowerment via intrinsic and extrinsic rewards. Academy of Health Care Management Journal, 4(1), 17-38.

[60] Grant, A., Dutton, J., \& Rosso, B. (2008). Giving commitment: Employee support programs and the prosocial sensemaking process. Academy of Management Journal, 51(5), 898-918. https://doi.org/10.5465/amj.2008.34789652.

[61] Greenberg, J., \& Baron, R. (1997). Behaviour in organizations: Understanding and managing the Human side of work. Prentice-Hall, New Jersey.

[62] Griffeth, R., Hom, P., \& Gaertner, S. (2000). A meta-analysis of antecedents and correlates of employee turnover: update, moderator tests, and research implications for the next millennium. Journal of Management, 26(3), 463-488. https://doi.org/10.1177\%2F014920630002600305.

[63] Gupta, S., \& Pannu, H. (2013). A comparative study of job satisfaction in public \& private sector. Indian Journal of Arts, 1(1), 3-6.

[64] Hair, J., Black, W., Babin, B., Anderson, R., \& Tatham, R. (2009). Multivariate Data Analysis. . Upper Saddle River, NJ: Pearson Prentice Hall.

[65] Halter, M., Boiko, O., Pelone, F., Beighton, C., Harris, R., Gale, J., Gourlay, S., Drennan, V. (2017). The determinants and consequences of adult nursing staff turnover: a systematic review of systematic reviews. BMC Health Services Research.

[66] Han, K., Trinkoff, A. M., \& Gurses, A. P. (2015). Work-related factors, job satisfaction and intent to leave the current job among United States nurses. Journal of Clinical Nursing, 24(21-22), 3224-3232. https://doi.org/10.1111/jocn.12987.

[67] Harmon, J., Scotti, D. J., Behson, S., Farias, G., Petzel, R., Neuman, J. H., (2003). Effects of High Involvement Work Systems on Employee Satisfaction and Service Costs in Veterans Healthcare. Journal of Healthcare Management, 48(6), 393-406.

[68] Hayes, L. J., O’Brien-Pallas, L., Duffield, C., Shamian, J., Buchan, J., Hughes, F., Laschinger, Heather K. S., North, N., Stone, P. W. (2006). Nurse turnover: A literature review. International Journal of Nursing Studies, 43(2), 237-263. https://doi.org/10.1016/j.ijnurstu.2005.02.007.

[69] Hayes, L., O’Brien-Pallas, L., Duffield, C., Shamian, J., Buchan, J., Hughes, F., Laschinger, Heather K. S., North, N. (2012). Nurse turnover: A literature review-An update. International Journal of Nursing Studies, 49(7), 887-905. https://doi.org/10.1016/j.ijnurstu.2011.10.001.

[70] Heijden, B. I., Peeters, M. C., Blanc, P. M., \& Breukelen, J. W. (2018). Job characteristics and experience as predictors of occupational turnover intention and occupational turnover in the European nursing sector. Journal of Vocational Behavior, 108 (2018), 108-120. https://doi.org/10.1016/j.jvb.2018.06.008.

[71] Hellman, C. (1997). Job satisfaction and intent to leave. Journal of Social Psychology, 137(6), 677-689. https://doi.org/10.1080/00224549709595491.

[72] Homans, G. C. (1961). The Humanities and the Social Sciences. American Behavioural Scientist, 4(8), 3-6. https://doi.org/10.1177\%2F000276426100400802.

[73] Hoppock, R. (1935). Job Satisfaction. New York: Harper and Brothers.

[74] Hussain, T., \& Asif S. (2012). Is employees' turnover intention driven by organizational commitment and perceived organizational support? Journal of Quality and Technology Management, 8(2), 01-10.

[75] Huyghebaert, T., Gillet, N., Becker, C., \& Kerhardy, S., Fouquereau, E. (2017). Examining the effect of affective commitment to the supervisor on nurses' psychological health as a function of internal locus of control. Journal of Nursing Management, 25(4), 297-306. https://doi.org/10.1111/jonm.12466.

[76] Iftikhar, M., Shahid, M. U., Shahab, M. H., Mobeen, M., \& Qureshi, M. I. (2015). Exploring the Relationship among Organizational Citizenship Behavior, Psychological Empowerment and Turnover Intensions with the Mediating Role of Affective Commitment. International Review of Management and Marketing, 6(4S), 296-304.

[77] Islam, T., Khan, M. M., \& Bukhari, F. H. (2016). The role of organizational learning culture and psychological empowerment in reducing turnover intention and enhancing citizenship behaviour. The Learning Organization, 23(2/3), 156-169. https://doi.org/10.1108/TLO-10-2015-0057.

[78] Ivancevich, J., \& Matteson, M. (2002). Organizational Behaviour and Management. New York: NY: McGraw-Hill.

[79] Javed, M., Balouch, R., \& Hassan, F. (2014). Determinants of Job Satisfaction and its Impact on Employee Performance and Turnover Intentions. International Journal of Learning \& Development, 4(2), 120-140. https://Doi:10.5296/ijld.v4i2.6094.

[80] Jha, S. (2011). Influence of psychological empowerment on affective, normative and continuance commitment: A study in the Indian IT industry. Journal of Indian Business, 3(4), 263-282. https://doi.org/10.1108/17554191111180582.

[81] Joarder, M., Sharif, M., \& Ahmmed, K. (2011). Mediating role of affective commitment in HRM practices and turnover intention relationship: A study in a developing context. Business \& Economics Research Journal, 2(4), 135-158.

[82] Jones, C. (1990a). Staff nurse turnover costs: Part I, a conceptual model. Journal of Nursing Administration, $20(4), 18-23$.

[83] Jones, C. (1990b). Staff nurse turnover costs: Part II, measurements and results. Journal of Nursing Administration, $20(5), 27-32$. 
[84] Kabene, S. M., Orchard, C., Howard, J. M., Soriano, M. A., \& Leduc, R. (2006). The importance of human resources management in health care: a global context. Human resources for health, 4(1), 1-17.

[85] Kankaanranta, T., \& Rissanen, P. (2008). Nurses' intentions to leave nursing in Finland. The European Journal of Health Economics, 9(4), 333-342.

[86] Khawaja, H. (2013). Nursing shortage in Pakistan- Human resource management in health system.

[87] Khowaja, K., Merchant, R. J., \& Hirani, D. (2005). Registered nurses perception of work satisfaction at a Tertiary Care University Hospital. Journal of Nursing Management, 13(1), 32-39. https://doi.org/10.1111/j.1365-2834.2004.00507.x

[88] Kirk-Brown, A., \& Dijk, P. V. (2015). An examination of the role of psychological safety in the relationship between job resources, affective commitment and turnover intentions of Australian employees with chronic illness. The International Journal of Human Resource Management, 27(14), 1626-1641. https://doi.org/10.1080/09585192.2015.1053964.

[89] Kitapci, O., Akdogan, C., \& Dortyol, I. T. (2014). The impact of service quality dimensions on patient satisfaction, repurchase intentions and wordof-mouth communication in the public healthcare industry. Procedia-Social and Behavioral Sciences, 148 (2014), 161-169. https://doi.org/10.1016/j.sbspro.2014.07.030.

[90] Klerk, S. de., \& Stander, M. W. (2014). Leadership Empowerment Behaviour, Work Engagement and Turnover Intention: The Role of Psychological Empowerment. Journal of Positive Management, 5(3), 28-45.

[91] Koberg, C. S., Boss, R. W., Senjem, J. C., \& Goodman, E. A. (1999). Antecedents and Outcomes of Empowerment: Empirical Evidence from the Health Care Industry. Group and Organization Management, 24(1), 71-91. https://doi.org/10.1177\%2F1059601199241005.

[92] Kwantes, C. (2009). Culture, job satisfaction and organizational commitment in India and the United States. Journal of Indian Business Research, 1(4), 196-212. https://doi.org/10.1108/17554190911013265.

[93] Kuo, H.-T., Lin, K.-C., \& Li, I.-C. (2013). The mediating effects of job satisfaction on turnover intention for long term care nurses in Taiwan. Journal of Nursing Management, 22(2), 225-233. https://doi.org/10.1111/jonm.12044.

[94] Labrague, L. J., Gloe, D., McEnroe, D. M., Konstantinos, K., \& Colet, P. (2018). Factors influencing turnover intention among registered nurses in Samar Philippines. Applied Nursing Research, 39(2018), 200-206. https://doi.org/10.1016/j.apnr.2017.11.027.

[95] Lambert, E., Hogana, N., \& Bartona, S. (2001). The impact of job satisfaction on turnover intent: A test of a structural measurement model using a national sample of workers. The Social Science Journal, 38(2), 233-250. https://doi.org/10.1016/S0362-3319(01)00110-0.

[96] Larrabee, J., Janney, M., Ostrow, C., Withrow, M., Hobbs, G., \& Burant, C. (2003). Predicting registered nurse job satisfaction and intent to leave. Journal of Nursing Administration, 33(5), 271-283.

[97] Laschinger, H., Finegan, J., Shamian, J., \& Wilk, P. (2001). Impact of structural and psychological empowerment on job strain in nursing work settings: expanding Kanter's Model. Journal of Nursing Administration, 31(5), 260-272.

[98] Laschinger, H. K., Finegan, J. E., Shamian, J., \& Wilk, P. (2004). A longitudinal analysis of the impact of workplace empowerment on work satisfaction. Journal of Organizational Behavior, 25(4), 527-545. https://doi.org/10.1002/job.256.

[99] Lashley, C. (1995). Towards an understanding of employee empowerment in hospitality services. International Journal of Contemporary Hospitality Management, 7(1), 27-32. https://doi.org/10.1108/09596119510078207.

[100] Lee, C., \& Bruvold, N. (2003). Creating value for employees: Investment in employee development. International Journal of Human Resource Management, 14(6), 981-1000. https://doi.org/10.1080/0958519032000106173

[101] Liden, R. C., Wayne, S. J., \& Sparrowe, R. T. (2000). An examination of the mediating role of psychological empowerment on the relations between the job, interpersonal relationships, and work outcomes. Journal of Applied Psychology, 85(3), 407-416. https://doi.org/10.1037/00219010.85.3.407

[102] Li, N., Zhang, L., Xiao, G., Chen, J., \& Lu, Q. (2019). The relationship between workplace violence, job satisfaction and turnover intention in emergency nurses. International Emergency Nursing, 45, 50-55. https://doi.org/10.1016/j.ienj.2019.02.001.

[103] LO, W.-Y., CHIEN, L.-Y., HWANG, F.-M., HUANG, N., \& CHIOU, S.-T. (2017). From job stress to intention to leave among hospital nurses: A structural equation modelling approach. Journal of Advanced Nursing, 74(3), 677-688. https://doi.org/10.1111/jan.13481.

[104] Locke, E. A. (1969). What is job satsiafaction. Organizational Behaviour and Human Performance, 4(4), 309-336. https://doi.org/10.1016/00305073(69)90013-0.

[105] Lockwood, C., \& MacKinnon, D. (1998). Bootstrapping the standard error of the mediated effect. Proceedings of the 23rd Annual Meeting of SAS Users Group International (997-1002). Cary, NC: SAS Institute, Inc.

[106] Long, C. S., \& Thean, L. Y. (2011). Relationship between leadership style, job satisfaction and employees' turnover intention: A literature review. Research Journal of Business Management, 5(3), 91-100.

[107] Lu, H., While, A. E., \& Barriball, K. L. (2005). Job satisfaction among nurses: a literature review. International Journal of Nursing Studies, 42(2), 211-227. https://doi.org/10.1016/j.ijnurstu.2004.09.003.

[108] Lu, H., While, A. E., \& Barriball, K. L. (2007). Job satisfaction and its related factors: a questionnaire survey of hospital nurses in Mainland China. International Journal of Nursing Studies, 44(4), 574-588. https://doi.org/10.1016/j.ijnurstu.2006.07.007.

[109] Lum, L., Kervin, J., Clark, K., Reid, F., \& Sirola, W. (1998). Explaining nursing turnover intent: job satisfaction, pay satisfaction, or organizational commitment? Journal of Organizational Behaviour, 19(3), 305-320. https://doi.org/10.1002/(SICI)10991379(199805)19:3\%3C305::AID-JOB843\%3E3.0.CO;2-N

[110] Ramalho Luz, C., Luiz de Paula, S. and de Oliveira, L. (2018). Organizational commitment, job satisfaction and their possible influences on intent to turnover. Revista de Gestão, 25(1), 84-101. https://doi.org/10.1108/REGE-12-2017-008

[111] Maister, D. (2001). Practice What You Preach. New York: The Free Press.

[112] Malik, M. I., Zaheer, A., Khan, M. A., \& Ahmed, M. (2010). Developing and testing a model of burnout at work and turnover intensions among doctors in Pakistan. International journal of business and management, 5(10), 234-247.

[113] Malik, O. F., Sattar, A., Shahzad, A., \& Faiz, R. (2017). Personal Bullying and Nurses' Turnover Intentions in Pakistan: A Mixed Methods Study. Journal of Interpersonal Violence, 1-21. https://doi.org/10.1177\%2F0886260517719903.

[114] Malik, O. F., Waheed, A., \& Malik, K.-U.-R. (2010). The Mediating Effects of Job Satisfaction on Role Stressors and Affective Commitment. International Journal of Business and Management, 5(11), 223-235.

[115] Marquis, B. L., \& Huston, C. J. (2009). Leadership roles and management functions in nursing: Theory and application. Lippincott Williams \& Wilkins.

[116] Mehmood, N., Ahmad, U. N., Irum, S., \& Ashfaq, M. (2016). Job Satisfaction, Affective Commitment, and Turnover Intentions among Front Desk Staff: Evidence from Pakistan. International Review of Management and Marketing, 6(4S), 305-309.

[117] Mensah, R., \& Kosi, I. (2016 ). Organizational Commitment and Turnover Intentions of Clinical Laboratory Scientists in Ghana. European Journal of Business and Management, 8(2), 164-172.

[118] Meyer, J., \& Herscovitch, L. (2001). Commitment in the Workplace: Toward a General Model. Human Resource Management Review, 11(3), 299-326. https://doi.org/10.1016/S1053-4822(00)00053-X.

[119] Meyer, J. P., \& Allen, N. J. (1991). A Three-Component Conceptualization of Organizational Commitment. Human Resource Management Review, 1(1), 61-89. https://doi.org/10.1016/1053-4822(91)90011-Z.

[120] Meyer, J. P., \& Allen, N. J. (1997). Commitment in the Workplace:Theory, Research and Application. Thousand Oaks London New Dehli: Sage Publications-International Educational and Professional Publisher.

[121] Meyer, J. P., \& Allen, N. J. (1984). Testing the "Side-Bet Theory" of Organizational Commitment: Some Methodological Considerations. Journal of Applied Psychology, 69(3), 372-378. https://psycnet.apa.org/doi/10.1037/0021-9010.69.3.372.

[122] Meyer, J., Stanley, D., Herscovitch, L., \& Topolnytsky, L. (2002). Affective, continuance, and normative commitment to the organization: A meta-analysis of antecedents, correlates, and consequences. Journal of Vocational Behavior, 61(1), 20-52. https://doi.org/10.1006/jvbe.2001.1842 
[123] Mobley, W. H., Griffeth, R. W., Hand, H. H., \& Meglino, B. M. (1979). Review and conceptual analysis of the employee turnover process. Psychological Bulletin, 86(3), 493-522. https://doi.org/10.1037/0033-2909.86.3.493

[124] Mosadeghrad, A. M., Ferlie, E., \& Rosenberg, D. (2008). A study of the relationship between job satisfaction, organizational commitment and turnover intention among hospital employees. Health Services Management Research, 21(4), 211-227. https://doi.org/10.1258\%2Fhsmr.2007.007015.

[125] Mowday, R., Porter, L., \& Steers, R. (1982). Employee-organization Linkages: The Psychology of Commitment, Absenteeism, and Turnover. New York: Academic Press.

[126] Mowday, R, T., Steers, R. M., \& Porter, L. W. (1979). The Measurement of Organizational Commitment. Journal of Vocational Behaviour, 14(2), 224-247. https://doi.org/10.1016/0001-8791(79)90072-1.

[127] Munir, Y., Ghafoor, M., \& Rasli, A. (2018). Perception of ethical climate and turnover intention among nursing staff: does organizational cynicism mediate? International Journal of Human Rights in Healthcare, 11(5), 319-332. https://doi.org/10.1108/IJHRH-07-2017-0028

[128] National Health Care Retention \& RN Staffing Report (2019). NSI Nursing Solutions, Inc.

[129] Naz, S., \& Gul, S. (2014). Moderating Role of Organizational Commitment between Communication Satisfaction and Turnover Intentions Among Nurses . Pakistan Journal of Psychological Research, 29(1), 39-52.

[130] Newman, A., Thanacoody, R., \& Hui, W. (2011). The impact of employee perceptions of training on organizational commitment and turnover intentions: a study of multinationals in the Chinese service sector. The International Journal of Human Resource Management, 22(8), 1765-1787. https://doi.org/10.1080/09585192.2011.565667.

[131] Ngo-Henha, P. E. (2017). A Review of Existing Turnover Intention Theories. International Journal of Economics and Management Engineering 11(11), 2760-2767.

[132] Nursing world: Recruitment and Retention of Nurses (2013). American Nurses Association.

[133] Oyeleye, O., Hanson, P., O’Connor, N., \& Dunn, D. (2013). Relationship of Workplace Incivility, Stress, and Burnout on Nurses' Turnover Intentions and Psychological Empowerment. The Journal of Nursing Administration, 43(10), 536-542. https://doi.10.1097/NNA.0b013e3182a3e8c9.

[134] Parasuraman, S. (1982). Predicting turnover intentions and turnover behavior: A multivariate analysis. Journal of Vocational Behavior, 21(1), 111-121. https://doi.org/10.1016/0001-8791(82)90056-2.

[135] Pathak, D., \& Srivastava, S. (2017). What makes employees stay? Role of psychological empowerment in organisational commitment-turnover intentions relationship: a study on Indian managers. International Journal of Indian Culture and Business Management, 14(2), 180-197.

[136] Perreira, T. A., Berta, W., \& Hebert, M. (2018). The Employee Retention Triad in Healthcare: Exploring Relationships among Organizational Justice, Affective Commitment and Turnover Intention. Journal of Clinical Nursing, 27(7-8), 1451-1461. https://doi.org/10.1111/jocn.14263.

[137] Peterson, S. (2004). Toward a theoretical model of employee turnover: A human resource development perspective. Human Resource Development Review, 3(3), 209-227. https://doi.org/10.1177\%2F1534484304267832.

[138] Preacher, K., \& Hayes, A. (2008). Asymptotic and resampling strategies for assessing and comparing indirect effects in multiple mediator models. Behavior Research Methods, 40(3), 879-891.

[139] Preacher, K., \& Hayes, A. (2004). SPSS and SAS procedures for estimating indirect effects in simple mediation models. Behavior Research Methods, Instruments, Computers, 36(4), 717-731.

[140] Preacher, K., Rucker, D., \& Hayes, A. (2007). Addressing moderated mediation hypotheses: Theory, methods, and prescriptions. Multivariate Behavioral Research, 42(1), 185-227. https://doi.org/10.1080/00273170701341316.

[141] Price, J. (2001). Reflections on the determinants of voluntary turnover. International Journal of Manpower, 22(7), 600-624 https://doi.org/10.1108/EUM0000000006233.

[142] Pronovost, P., Berenholtz, S., Dorman, T., Lipsett, P. A., Simmonds, T., \& Haraden, C. (2003). Improving communication in the ICU using daily goals. Journal of critical care, 18(2), 71-75. https://doi.org/10.1053/jcrc.2003.50008

[143] Rainey, H. (1997). Understanding and Managing Public Organizations. Jossey-Bass, San Francisco, CA

[144] Ramoo, V., Abdullah, K. L., \& Piaw, C. Y. (2013). The relationship between job satisfaction and intention to leave current employment among registered nurses in a teaching hospital. Journal of Clinical Nursing, 22(21-22), 3141-3152. https://doi.org/10.1111/jocn.12260.

[145] Rana, T. M., Salaria, M. R., Herani, G. M., \& Amin, M. (2009). Identifying Factors Playing Important Role in the Increasing Employees' Turnover Rate: A Case of Telecom Industry in Pakistan. Indus Journal of Management and Social Sciences, 3(2), 80-89.

[146] Rathert, C., \& May, D. R. (2007). Health care work environments, employee satisfaction, and patient safety: Care provider perspectives. Health care management review, 32(1), 2-11.

[147] Richardson, L. (2019). The Relationship between Leader Empowering Behaviors and Employees' Structural and Psychological Empowermen among Mental Health Professionals (Doctoral dissertation, Grand Canyon University)

[148] Roelen, C., Magerøy, N., Rhenen, W. van., Groothoff, J., Klink, J. van., Pallesen, S., Bjorvatn, B., Moen, B. (2013). Low job satisfaction does not identify nurses at risk of future sickness absence: Results from a Norwegian cohort study. International Journal of Nursing Studies, 50(3), 366373. https://doi.org/10.1016/j.ijnurstu.2012.09.012

[149] Rothrock, J. C. (2007). Attracting and Keeping New Graduates. AORN Journal, 85(6), 1063-1064.

[150] Rousseau, D. (1989). Psychological and Implied Contracts in Organizations. Employee Responsibilities and Rights Journal, 2(2), 121-139.

[151] Saha, S., \& Kumar, S. P. (2018). Organizational culture as a moderator between affective commitment and job satisfaction: Empirical evidence from Indian public sector enterprises. International Journal of Public Sector Management, 31(2), 184-206. https://doi.org/10.1108/IJPSM-03-2017$\underline{0078}$.

[152] Sajjad, A., Ghazanfar, H., \& Ramzan, M. (2013). Impact of motivation on employee turnover in telecom sector of Pakistan. Journal of Business Studies Quarterly, 5(1), 76-92

[153] Salahudin, S. N., Alwi, M. N., Baharuddin, S. S., \& Samad, N. I. (2016). Generation Y: Organizational Commitment and Turnover Intention. The European Proceedings of Social and Behavioural Sciences, 448-456. https://doi.org/10.15405/epsbs.2016.11.02.41.

[154] Sarmiento, T. P., Laschinger, H. K.S, \& Iwasiw, C. (2003). Nurse educators' workplace empowerment, burnout, and job satisfaction: testing Kanter's theory. Issues and Innovations in Nursing Education, 46(2), 134-143. https://doi.org/10.1111/j.1365-2648.2003.02973.x

[155] Scholl, R. (1981). Differentiating Commitment From Expectancy as a Motivating Force. Academy of Management Review, 6(4), 589-599. https://doi.org/10.5465/amr.1981.4285698

[156] Shah, S. H., \& Beh, L.-S. (2016). The Impact of Motivation Enhancing Practices and Mediating Role of Talent Engagement on Turnove Intentions: Evidence from Malaysia. International Review of Management and Marketing, 6(4), 823-835. https://dergipark.org.tr/en/pub/irmm/issue/32102/355696.

[157] Shah, S. M., Ali, R., Dahri, A. S., Brohi, N. A., Maher, Z. A., \& Hameed, W. u. (2018). Determinants of Job Satisfaction among Nurses: Evidence from South Asian Perspective. International Journal of Academic Research in Business and Social Sciences, 8(5), 19-26. http://dx.doi.org/10.6007/IJARBSS/v8-i5/4082.

[158] Shahzad, A., \& Malik, R. K. (2014). Workplace Violence: An Extensive Issue for Nurses in Pakistan-: A Qualitative Investigation. Journal of Interpersonal Violence, 29(11), 2021-2034. https://doi.org/10.1177\%2F0886260513516005.

[159] Shazali, N. A., Habidin, N. F., Ali, N., Khaidir, N. A., \& Jamaludin, N. H. (2013). Lean healthcare practice and healthcare performance in Malaysian healthcare industry. International Journal of Scientific and Research Publications, 3(1), 1-5.

[160] Siqueira, M. (2008). Medidas do Comportamento Organizacional: ferramentas de diagnóstico e de gestão. Porto Alegre: Artmed, 27, 114-115.

[161] Spector, P. E. (1985). Measurement of Human Service Staff Satisfaction: Development of the Job Satisfaction Survey. American Journal of Community Psychology, 13(6), 693-713. https://doi.org/10.1007/BF00929796.

[162] Spreitzer, G. M. (1995). Psychological Empowerement in the WorkPlace: Dimensions, Measurement and Validation. Academy of Management Journal, 38(5), 1442-1465. https://doi.org/10.5465/256865. 
[163] Steel, R. P., \& Lounsbury, J. W. (2009). Turnover process models: Review and synthesis of a conceptual literature. Human Resource Management Review, 19(4), 271-282. https://doi.org/10.1016/j.hrmr.2009.04.002.

[164] Strachota, E., Normandin, P., O’Brien, N., Clary, M., \& Krukow, B. (2003). Reasons registered nurses leave or change employment status. Journal of Nursing Administration, 33(2), 111-117.

[165] Tett, R.P., \& Meyer, J. P. (1993). Job satisfaction, organizational commitment, turnover intention, and turnover: path analysis based on metaanalytic findings. Personnel Psychology, 46 (2), 259-293. https://doi.org/10.1111/j.1744-6570.1993.tb00874.x.

[166] The Express Tribune. Chauhan, Nisma (7, December 2014). Nursing in Pakistan: Handle with care.

[167] Thomas, K. W., \& Velthouse, B. A. (1990). Cognitive Elements of Empowerment: An "Interpretive" Model of Intrinsic Task Motivation. Academy of Management Review, 15(4), 666-681. https://doi.org/10.5465/amr.1990.4310926.

[168] Tzeng, H-M. Ketefian, S., \& Redman, R.W. (2002). Relationship of nurses' assessment of organizational culture, job satisfaction, and patient satisfaction with nursing care. International Journal of Nursing Studies, 39(1), 79-84. https://doi.org/10.1016/S0020-7489(00)00121-8.

[169] Tzeng, H.-M. (2002). The influence of nurses'working motivation and job satisfaction on intention to quit: an empirical investigation in Taiwan International Journal of Nursing Studies, 39(8), 867-878. https://doi.org/10.1016/S0020-7489(02)00027-5.

[170] Tzeng, H., Yang, C., \& Lee, S. (2001). Brief report: the. relationship between patient satisfaction and health care providers'job satisfaction: an exploratory study on the 11 metropolitan public health care institutions in Taiwan. Hospital (Taiwan), 34(4), 16-23.

[171] Wagner, J. I.J., Cummings, G., Smith, D. L., Olson, J., Anderson, L., \& Warren, S. (2010). The relationship between structural empowerment and psychological empowerment for nurses: a systematic review. Journal of Nursing Management, 18(4), 448-462. https://doi.org/10.1111/j.13652834.2010.01088.x.

[172] Waldman, J. D., Kelly, F., Arora, S., \& Smith, H. L. (2004). The Shocking Cost of Turnover in Health Care. Health Care Management Review, 29(1), 2-7.

[173] Withey, M. (1988). Antecedents of value based and economic organizational commitment. In S.L. McShane (Ed.). Proceedings of the Annual Meeting of the Administrative Science Association of Canada: Organizational Behavior, 9, 124-133.

[174] Villiers, J. R.de., \& Stander, M. W. (2011). Psychological Empowerment, Work Engagement and Turnover Intention: The Role of Leader Relations and Role Clarity in a Financial Institution. Journal of Psychology in Africa, 21(3), 405-412. https://doi.org/10.1080/14330237.2011.10820474.

[175] Vroom, V. (1964). Work and Motivation. New York: John Wiley.

[176] Yang, C. C., \& Lin, C. Y. Y. (2009). Does intellectual capital mediate the relationship between HRM and organizational performance? Perspective of a healthcare industry in Taiwan. The International Journal of Human Resource Management, 20(9), 1965-1984. https://doi.org/10.1080/09585190903142415.

[177] Yin, J-C.T., \& Yang, K-P.A. (2002). Nursing turnover in Taiwan: a meta-analysis of related factors. International Journal of Nursing Studies, 39(6), 573-581. https://doi.org/10.1016/S0020-7489(01)00018-9.

[178] Yücel, İ. (2012). Examining the Relationships among Job Satisfaction, Organizational Commitment, and Turnover Intention: An Empirical Study. International Journal of Business and Management, 7(20), 44-58. https://doi:10.5539/ijbm.v7n20p44

[179] Fornell, C., \& Larcker, D.F. (1981). Evaluating structural equation models with unobservable variables and measurement error. Journal of Marketing Research, 18(1), 39-50. https://doi.org/10.1177\%2F002224378101800104. 